\title{
A survey for the Sierra Madre Sparrow (Xenospiza baileyi), with its rediscovery in the state of Durango, Mexico
}

\author{
ADÁN OLIVERAS DE ITA and OCTAVIO R. ROJAS-SOTO
}

\section{Summary}

The Sierra Madre Sparrow (Xenospiza baileyi) is a highly endangered and endemic species of the highlands of south-central Mexico, where it is resident in bunchgrass (Gramineae) and adjacent marshy habitats in the southern Sierra Madre Occidental (Jalisco and Durango states) and in the mountains around the Valley of Mexico (Distrito Federal and the states of Morelos and Mexico). This species was first collected in the southern part of this range on 23 April 1945 at La Cima, D.F., where its persistence has been documented essentially continuously since 1951. The first specimens of the taxon were collected in the Sierra de Bolaños of extreme northern Jalisco on 3-10 March 1889, including the type from which the genus and species were described in 1931. Two populations have been found in southern Durango: one 30 miles $(48 \mathrm{~km})$ south-west of the City of Durango on 22 March 1931, and the other 5 miles (8 km) west of El Salto on 16-17 June 1951. The Sierra Madre Sparrow has not been otherwise confirmed in the northern part of its range, which in July 2004 led us to conduct an extensive search for it in these areas of Durango and Jalisco as well as south-western Zacatecas. Here we present the findings from that search, during which several sites were intensively surveyed and a single population of this sparrow was located - a new one between the city of Durango and El Salto, Durango. This rediscovery increases possibilities for understanding the biogeography, ecology and basic requirements of the Sierra Madre Sparrow, information of fundamental importance for proposing measures that promote its conservation in any of its remaining populations.

\section{Introduction}

The Sierra Madre Sparrow (Xenospiza baileyi; Emberizidae, Passeriformes) was first discovered by W. B. Richardson, who collected a series of eight museum skins in the Sierra de Bolaños, extreme northern Jalisco, on 3-10 March 1889 (Navarro et al. 2002). Of these specimens, seven were deposited in the British Museum (Natural History) in 1899 (one was exchanged to the Smithsonian Institution in 1939), where they were misidentified as either Song (Melospiza [melodia] adusta) or Savannah (Passerculus sandwichensis) sparrows (R. Prys-Jones in litt. 2004). The eighth of these skins was acquired by the Museum of Comparative Zoology at Harvard University, where it was long regarded as a hybrid by such eminent ornithologists as Robert Ridgway and Harry C. Oberholser (Bangs 1931). However, that identification was overturned on 22 March 1931, when Alfred H. Bailey collected a specimen from a small population of these birds $48 \mathrm{~km}$ south-west of the city of Durango in southern Durango (Bailey and Conover 1935). That skin was soon sent to Bangs (1931: 86), who used it and the MCZ specimen (no. 45986; designated holotype) to describe this 
sparrow as a new genus and species - the epithet of which honors Bailey. While ornithologists have agreed that this species is quite distinct, their assessments have differed as to its relationships and whether Xenospiza is a valid genus. Dickerman et al. (1967), Robins and Schnell (1971) and Howell and Webb (1995) consider that the Sierra Madre Sparrow is a member of the Ammodramus complex (sensu lato), although in other ways it appears more like Melospiza (Pitelka 1947, J. Klicka verbally 2003) or Passerculus (H. Gómez de Silva verbally 2002).

A second Durango population of the Sierra Madre Sparrow was found by John Davis, who on 16-17 June 1951 collected five skins at San Juan, which is located 5 miles $(8 \mathrm{~km}$ ) west of El Salto (Navarro et al. 2002). That was 6 years after this species had first been discovered in the Valley of Mexico region by Helmut O. Wagner, who obtained an adult male at La Cima, 3,00o m, Distrito Federal on 23 April 1945 (Museum of Vertebrate Zoology). That skin (MVZ 93519) became the holotype and only known example of X. b. sierrae, which Frank A. Pitelka (1947) distinguished from the nominate population (Jalisco and Durango) primarily on the basis of plumage differences. In 1949-1950, Wagner obtained at least five additional skins of this species at La Cima and nearby Fierro del Toro, Morelos (Navarro et al. 2002). In July 1954, Robert W. Dickerman, Allan R. Phillips and Dwain W. Warner (1967) began studying the status, behaviour, habitat use, and other aspects of the biology of the La Cima population. In addition, they amassed skins of at least 44 adults and 1o juveniles to document the plumages, moults, soft-part colours, skeletal characteristics, standard measurements, reproductive status and related parameters in those birds. They also used this material to assess geographic variation in this species, from which they concluded that $X . b$. sierrae is not a valid subspecies - thus making the Sierra Madre Sparrow monotypic.

Dickerman et al. (1967) provided the first detailed information on habitat utilization in the Sierra Madre Sparrow, based on their study of the population at La Cima. They found that these birds were associated primarily with "medium and tall bunchgrasses, Festuca amplisima, Stipa ichu, Muhlenbergia affinis and M. macroura, interspersed with park-like stands of Pinus montezumae on the ridges and knolls." Earlier, Bailey and Conover (1935) had described the habitat of the Durango population as "the dried grass of a small marsh" in an area "near a series of springs," with the "sad pine" (probably Pinus lumholtzii) growing "upon the hot hillsides in whitish rock". Bailey (in Bangs 1931) further described the "small marsh (as some) fifty feet long $(15 \mathrm{~m})$ by perhaps twenty feet $(6 \mathrm{~m})$ across, grown to tall grass, dead at this season of the year (March)". The elevation of that locality was given as 8,000 feet $(2,438 \mathrm{~m})$. Dickerman et al. (1967) were also the first to address habitat loss for the Sierra Madre Sparrow, indicating that at La Cima "in the period since 1954 . . a large portion of the tillable area of this (grassland) ... has been plowed and destroyed as nesting cover. Approximately 25 to $35 \%$ of the habitat visited by the authors has been destroyed in this time span". Similar or even greater losses have occurred elsewhere in this bird's habitat (Oliveras de Ita et al. 2001), thus making it one of the 28 Mexican species considered as endangered to the point of facing global extinction (BirdLife International 2004). Despite searches (Howell 1999, Lammertink 1999, J. Rojas Tomé verbally 2001, J. Klicka verbally 2005), Sierra Madre Sparrow has not been detected in Jalisco since 1889 nor Durango since 1951 (see above), leading to the belief that the species is currently restricted to the remaining subalpine bunchgrasses in and near the southern Valley of Mexico (Howell and Webb 1995, Howell 1999, Oliveras de Ita and 
Gómez de Silva 2002). Given this, in 2004 we undertook a survey for the species in those two northern states and adjacent Zacatecas, as outlined below.

\section{Methods}

Between 14 and 31 July 2004, a time when the males are more conspicuous as a consequence of the territorial behaviour, we conducted an extensive search for Xenospiza baileyi in the Sierra Madre Occidental region of northwest-central Mexico (Fig. I, Table 1). This survey covered approximately $3,500 \mathrm{~km}$, beginning in extreme northern Jalisco, then proceeding northward through south-western Zacatecas, and finally westward to be completed in southern Durango. This region was chosen on the basis of historical occurrences of this bird, the potential presence of its habitat, and related considerations (Bailey and Conover 1935, Miller et al. 1957, Navarro et al. 2002). Our survey emphasized searches of bunchgrass associations (well-known locally as 'Pajón') in open areas and, when present, adjacent marshy areas, which we located both on our own and through interviews with agriculturists, cattlemen and local residents. Once such habitats were located, we first listened for these birds for to to 15 minutes while also searching for them with $9 \times 25$ and $10 \times 50$ binoculars and a Pentax $30 \times$ telescope. If none were detected, we then used a tape recorder to play several songs and calls of these sparrows as recorded from the Valley of Mexico population. If this procedure failed to elicit a response after at least 10 minutes, we

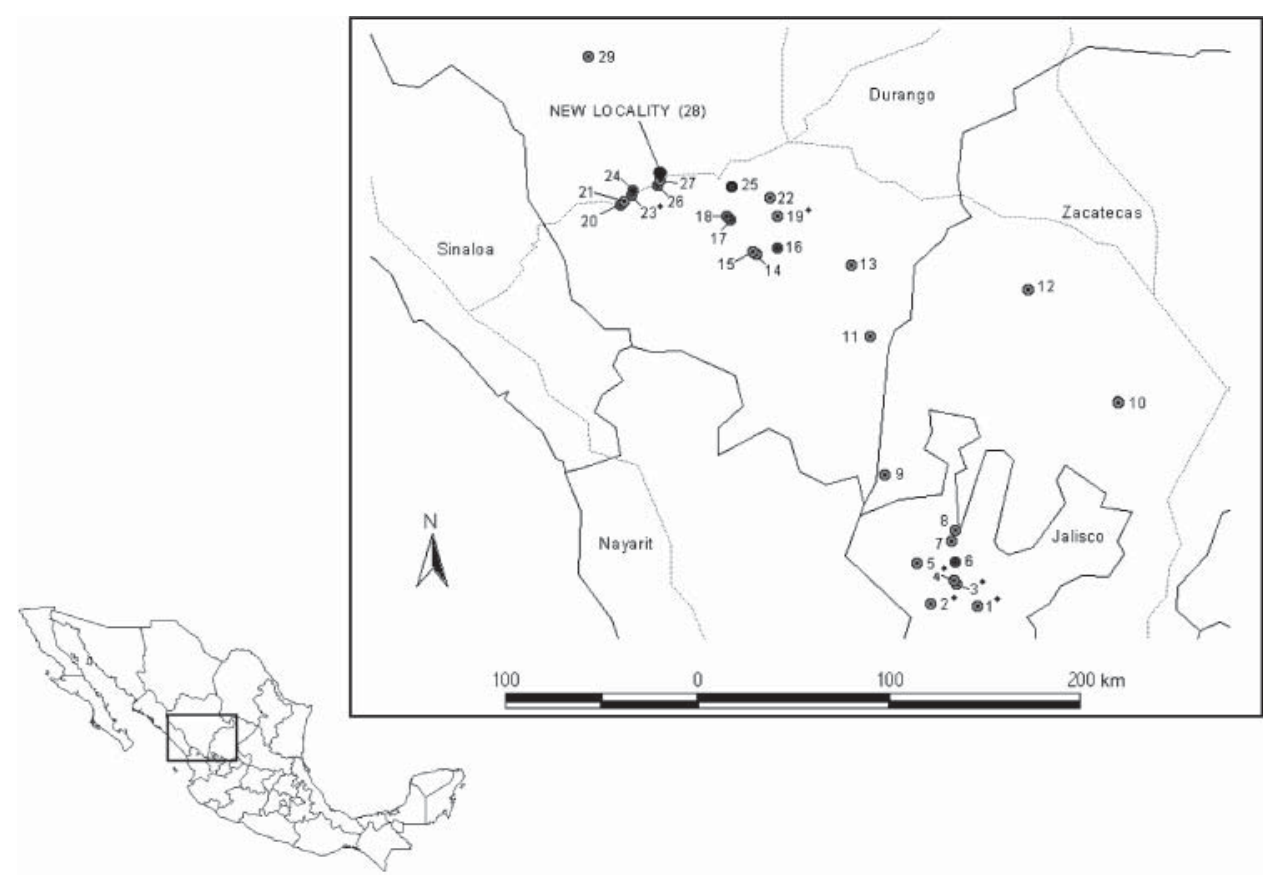

Figure 1. Location of the sites visited (grey points) and the new record (black point). Numbers correspond to the sites of Table 1 . The black and grey lines represent, respectively, state limits and the principal highways. Numbers with asterisks correspond to historic records, even though there is a lack of precision for the locality 'Sierra de Bolaños' (numbers 1, 2, 3, 4). 
Table 1. Localities visited and the numbers represented in Fig. 1. For each locality geographical coordinates, altitude and the name of the States are provided.

\begin{tabular}{|c|c|c|c|c|c|}
\hline Locality & Number & Latitude & Longitude & Altitude (m) & State \\
\hline Bolaños & 1 & $21^{\circ} 50^{\prime} 28^{\prime \prime} \mathrm{N}$ & $103^{\circ} 46^{\prime} 50^{\prime \prime} \mathrm{W}$ & 980 & Jalisco \\
\hline Tuxpan de Bolaños & 2 & $21^{\circ} 51^{\prime} 47 \cdot I^{\prime \prime} \mathrm{N}$ & $104^{\circ} \mathrm{OO}^{\prime} \mathrm{O} 2.2^{\prime \prime} \mathrm{W}$ & 1,847 & Jalisco \\
\hline Crucero Banderitas & 3 & $21^{\circ} 56^{\prime} 40^{\prime \prime} \mathrm{N}$ & $103^{\circ} 52^{\prime} 40^{\prime \prime} \mathrm{W}$ & 2,430 & Jalisco \\
\hline Bajío de Banderitas & 4 & $21^{\circ} 57^{\prime} 37 \cdot 1^{\prime \prime} \mathrm{N}$ & $103^{\circ} 53^{\prime} 12^{\prime \prime} \mathrm{W}$ & 2,430 & Jalisco \\
\hline Bajío el Tule & 5 & $22^{\circ} \mathrm{OI}^{\prime} \mathrm{O} 4^{\prime \prime} \mathrm{N}$ & $103^{\circ} 54^{\prime} 30^{\prime \prime} \mathrm{W}$ & 2,470 & Jalisco \\
\hline Bajío las Cebolletas & 6 & $22^{\circ} \mathrm{O}^{\prime} 27^{\prime \prime} \mathrm{N}$ & $103^{\circ} 53^{\prime} 40.4^{\prime \prime} \mathrm{W}$ & 2,538 & Jalisco \\
\hline Bajío los Amoles & 7 & $22^{\circ} 09^{\prime} 59 \cdot 4^{\prime \prime} \mathrm{N}$ & $103^{\circ} 54^{\prime}$ 09.1"W & 2,300 & Jalisco \\
\hline 8 km NE Bajío los Amoles & 8 & $22^{\circ} 12^{\prime} 04^{\prime \prime} \mathrm{N}$ & $103^{\circ} 53^{\prime} \mathrm{O} 2.7^{\prime \prime} \mathrm{W}$ & 2,415 & Jalisco \\
\hline Santa Lucía de la Sierra & 9 & $22^{\circ} 27^{\prime} 36^{\prime \prime} \mathrm{N}$ & $104^{\circ} 12^{\prime} 36^{\prime \prime} \mathrm{W}$ & 2,400 & Zacatecas \\
\hline Sarabia & 10 & $22^{\circ} 48^{\prime} 58.5^{\prime \prime} \mathrm{N}$ & $103^{\circ} 07^{\prime} 45.6^{\prime \prime} \mathrm{W}$ & 2,326 & Zacatecas \\
\hline Mesa la Gloria & 11 & $23^{\circ} \mathrm{O} 7^{\prime} 15.1^{\prime \prime} \mathrm{N}$ & $104^{\circ} 17^{\prime} 5^{\prime \prime} \mathrm{W}$ & 2,717 & Durango \\
\hline Rancho Gachupines & 12 & $23^{\circ} 20^{\prime} 14^{\prime \prime} \mathrm{N}$ & $103^{\circ} 32^{\prime} 34^{\prime \prime} \mathrm{W}$ & 2,600 & Zacatecas \\
\hline Mezquital & 13 & $23^{\circ} 27^{\prime} 22.7^{\prime \prime} \mathrm{N}$ & $104^{\circ} 22^{\prime} \mathrm{O} 2.9^{\prime \prime} \mathrm{W}$ & 1,661 & Durango \\
\hline Las Bayas & 14 & $23^{\circ} 30^{\prime} 13.7^{\prime \prime} \mathrm{N}$ & $104^{\circ} 49^{\prime} 27.0^{\prime \prime} \mathrm{W}$ & 2,649 & Durango \\
\hline Las Bayas Viejas & 15 & $23^{\circ} 31^{\prime} 06.1^{\prime \prime} \mathrm{N}$ & $104^{\circ} 50^{\prime} \mathrm{O} 2.6^{\prime \prime} \mathrm{W}$ & 2,552 & Durango \\
\hline La Flor & 16 & $23^{\circ} 32^{\prime} 05 \cdot 9^{\prime \prime} \mathrm{N}$ & $104^{\circ} 43^{\prime} 23.9^{\prime \prime} \mathrm{W}$ & 2,676 & Durango \\
\hline Bajío los Aguinaldos & 17 & $23^{\circ} 40^{\prime} 55.9^{\prime \prime} \mathrm{N}$ & $104^{\circ} 56^{\prime} 56.2^{\prime \prime} \mathrm{W}$ & 2,453 & Durango \\
\hline $2 \mathrm{~km}$ NE Bajío los Aguinaldos & 18 & $23^{\circ} 41^{\prime} 31.5^{\prime \prime} \mathrm{N}$ & $104^{\circ} 57^{\prime} 15 \cdot 7^{\prime \prime} \mathrm{W}$ & 2,444 & Durango \\
\hline Ciénega de Tableteros & 19 & $23^{\circ} 41^{\prime} 21.4^{\prime \prime} \mathrm{N}$ & $104^{\circ} 43^{\prime} 18.4^{\prime \prime} \mathrm{W}$ & 2,389 & Durango \\
\hline Las Juntas & 20 & $23^{\circ} 44^{\prime} 17 \cdot I^{\prime \prime} \mathrm{N}$ & $105^{\circ} 27^{\prime} 25 \cdot 3^{\prime \prime} \mathrm{W}$ & 2,671 & Durango \\
\hline Lechería & 21 & $23^{\circ} 45^{\prime} 41.5^{\prime \prime} \mathrm{N}$ & $105^{\circ} 26^{\prime} 37.2^{\prime \prime} \mathrm{W}$ & 2,699 & Durango \\
\hline La Casita & 22 & $23^{\circ} 46^{\prime} 29 \cdot 0^{\prime \prime} \mathrm{N}$ & $104^{\circ} 45^{\prime} 53 \cdot 7^{\prime \prime} \mathrm{W}$ & 2,459 & Durango \\
\hline San Juan & 23 & $23^{\circ} 47^{\prime} 14 \cdot 3^{\prime \prime} \mathrm{N}$ & $105^{\circ} 24^{\prime} 50.2^{\prime \prime} \mathrm{W}$ & 2,603 & Durango \\
\hline Mil Diez & 24 & $23^{\circ} 48^{\prime} 19^{\prime \prime} \mathrm{N}$ & $105^{\circ} 23^{\prime} 35 \cdot 4^{\prime \prime} \mathrm{W}$ & 2,589 & Durango \\
\hline Rancho Santa Bárbara & 25 & $23^{\circ} 49^{\prime} 20^{\prime \prime} \mathrm{N}$ & $104^{\circ} 55^{\prime} 40^{\prime \prime} \mathrm{W}$ & 2,300 & Durango \\
\hline Desviación a San & 26 & $23^{\circ} 50^{\prime} 59.8^{\prime \prime} \mathrm{N}$ & $105^{\circ} 17^{\prime} 51.8^{\prime \prime} \mathrm{W}$ & 2,450 & Durango \\
\hline Miguel de Cruces & & & & & \\
\hline $\begin{array}{l}\text { Ejido Ojo de Agua } \\
\text { El Cazador (town) }\end{array}$ & 27 & $23^{\circ} 51^{\prime} 55 \cdot 6^{\prime \prime} \mathrm{N}$ & $105^{\circ} 16^{\prime} 12.1^{\prime \prime} \mathrm{W}$ & $2,45^{1}$ & Durango \\
\hline $\begin{array}{l}\text { Ejido Ojo de Agua } \\
\text { El Cazador (locality) }\end{array}$ & 28 & $23^{\circ} 53^{\prime} 21.9^{\prime \prime} \mathrm{N}$ & $105^{\circ} 16^{\prime} 44 \cdot 5^{\prime \prime} \mathrm{W}$ & 2,341 & Durango \\
\hline $\begin{array}{l}\text { Desviación a Veracruz } \\
\text { de la Sierra }\end{array}$ & 29 & $24^{\circ} 26^{\prime} 06.0^{\prime \prime} \mathrm{N}$ & $105^{\circ} 36^{\prime} 33.1^{\prime \prime} \mathrm{W}$ & 2,612 & Durango \\
\hline
\end{tabular}

walked throughout the bunchgrasses to increase the possibility of detection; if the species was not recorded, we considered that site as uninhabited by the Sierra Madre Sparrow.

\section{Results}

As indicated above, the only Jalisco record of the Sierra Madre Sparrow is that based on W. B. Richardson's specimens, which were obtained on 3-10 March 1889 in the "Sierra de Bolaños, apparently a town" (Navarro et al. 2002). Given the inexactness of that locality, we searched for this species and its habitat throughout that mountain range and its vicinity, with standardized surveys conducted at sites 3-8 (Fig. I, Table 1 ). In addition, we also surveyed for it near the towns of Bolaños (site 1 ) and Tuxpan de Bolaños (site 2), even though they seem far too arid to have harboured these birds. All these sites proved unfruitful for this species, including in the 
mountains where the bunchgrasses have been completely replaced with cultivated areas and pastures over the last 30 years or more. This montane area is probably the same as that Goldman (1951) referred to as the "Sierra Madre, near Bolaños", where his party conducted a biological survey on 15-17 September 1897. He described the range as being "about 14 miles $(22.5 \mathrm{~km})$ " north-west of Bolaños, with "the top . . a rolling tableland 7,500 to 8,500 feet $(2,286-2,591 \mathrm{~m}$ ) high and 3 or 4 miles (4.8 or $6.4 \mathrm{~km}$ ) broad". The vegetation there was said to consist "mainly [of] several species of pines (Pinus spp.), oaks (Quercus spp.) and madroños (Arbutus spp.)". No bunchgrasses or marshes were mentioned, which suggests that they were not prominent features of the surveyed habitats. We also searched for the Sierra Madre Sparrow in Zacatecas, where our surveys in widely separated montane areas yielded none of these birds. However, we found only a few and scattered bunchgrasses in that state, some of which local residents said have been introduced in recent years.

Given that Xenospiza baileyi was recorded in Durango in 1931 and 1951, we reasoned it would be the most likely area in which populations of this species might still persist in the Sierra Madre Occidental. For this reason, we conducted a search for the species and its habitat in the southern part of that state from 20 to 31 July. During that time, we intensively surveyed several sites, as illustrated in Fig. 1 and detailed in Table 1 . We began our search near the Zacatecas border and gradually surveyed north-westerly to the site which we are certain is where Bailey and Conover (1935) found the first Durango population of this species. They referred to that locality as the "Cienega Tableterra", which was said to be "near a series of springs" about 15 miles $(24 \mathrm{~km})$ south of La Casita by way of the "Bajia de los Coconos". We found a locality called the "Ciénega de Tableteros" which is indeed near the "Valle de los Cóconos". However, the Ciénega (marshy area) is only $10 \mathrm{~km}$ south of La Casita, which distance obviously differs from the above. This is probably because Bailey and Conover's was an estimate, which was further distorted by travelling by pack train along topographic contours rather than in a straight line. In any case, the marsh has disappeared and in its place are crops and livestock, while the springs have been connected to pipes and cemented. The locality still supports some bunchgrass, but this grows only on the very steep, rocky hillsides where it is protected from livestock grazing. Given these changes, it is not surprising that we did not find the Sierra Madre Sparrow in the area.

The second Durango locality for the species was at "San Juan, 5 miles $(8 \mathrm{~km})$ west of El Salto, 8,80o feet $(2,682 \mathrm{~m})$ " where five specimens were collected by John Davis (Miller et al. 1957, Navarro et al. 2002). We determined the elevation of this site as 2,603 m (Fig. 1, Table 1), and no evidence was found of this species' persistence there. According to a local resident, the former habitat there was bunchgrass and marshy areas. However, these have been almost completely removed from the area, except for some bunchgrass remnants along the small streams and as ground cover in the pine forests. We also searched small fragments of seemingly suitable habitat at other sites near El Salto, but we did not find the species there either. The northernmost locality visited was $70 \mathrm{~km}$ north of El Salto at 'Desviación a Veracruz de la Sierra', which is on the highway to San Miguel de Cruces. It also proved fruitless for Sierra Madre Sparrows, despite the presence of extensive marshy meadows there - albeit lacking bunchgrasses. We did find better habitat at the 'Bajío de los Aguinaldos', which belongs to the Rancho Santa Barbara and is located south-east of the city of Durango. For example, that open area supported a remnant stand of bunchgrasses consisting of about 2 ha and surrounded by pine forest. Given these characteristics together with 
the abundance and density of the bunchgrasses, we anticipated that the sparrow might inhabit that site. However, we could not find it there, despite our intensive search of the entire locality.

On the twelfth day of our search, we visited the 'Ejido Ojo de Agua-El Cazador' (Fig. 1, Table 1). This site is located $6.5 \mathrm{~km}$ north of the Cruz de Piedra bypass at kilometer 86 of the federal highway no. 40 between the city of Durango and Mazatlán, Sinaloa, where there is a marshy meadow of about 80 ha with a few remnant clumps or stands of dense bunchgrass growing mainly on drier sites. Here we heard and observed our first individuals of Xenospiza baileyi in the Sierra Madre Occidental! The first was singing from the stalks of grasses and other flowering plants $(20-45 \mathrm{~cm}$ high) that grew near the bunchgrasses. During the following 2 days, we mist-netted and banded four adults (three males and one female) of the species, which were respectively sexed by the presence of a cloacal protuberance or brooding patch. We also found a nest with three young about 9 days old according to Geupel and Hardesty (1996), which were still being fed by both parents. All the captures took place within 50-80 $\mathrm{m}$ of each other, within which area the nest was also located. Based on this information, we believe at least three breeding pairs of the Sierra Madre Sparrow were present at this site, all concentrated in an area of approximately 0.5 ha. The males were singing, and they readily responded to our playing of recorded songs and calls of the species. The lack of additional females in our sample may because they were incubating eggs and/or brooding small young, making them less mobile and conspicuous. Females were also detected less often than males (i.e. $51 \%$ ) at this stage of the annual cycle in the La Cima population of this bird (based on data in Oliveras de Ita 2002).

\section{Discussion}

We are gratified to report the continued existence of the Sierra Madre Sparrow in the Sierra Madre Occidental of Mexico, namely at the Ejido Ojo de Agua-El Cazador in the southern portion of the state of Durango as of July 2004. Otherwise, this highly endangered, endemic species and genus is known to persist only in the mountains of the Transvolcanic Belt of south-central Mexico, most notably at La Cima and Milpa Alta in the Distrito Federal. In addition, a few individuals have recently been found some $6 \mathrm{~km}$ north-east of Coexapa in the state of Mexico (Oliveras de Ita and Gómez de Silva 2002).

This sparrow is entirely dependent on subalpine $(2,300-2,600 \mathrm{~m})$ bunchgrass habitat, which has disappeared over most of its range due to agricultural development, livestock grazing, and other such activities. The future of the Sierra Madre Sparrow is in such doubt that it is considered a globally endangered taxon (BirdLife International 2004). The key to its survival is clearly the protection and restoration of its habitat, which will require the combined efforts of governments, non-governmental organizations, academic institutions, private landowners and others. As for the Ejido Ojo de Agua-El Cazador population, its very small size and apparent isolation combined with limited habitat availability make it highly vulnerable to extinction. Even now its survival is threatened not only by livestock grazing and potential agricultural development, but also by the fact the Mexican army conducts bimonthly weapons tests and firearms practice in the area. On the other hand, many of the Ejido members are enthusiastic about the discovery of population of a bird that occurs only in Mexico, including the Comisariado Ejidal Don Julio Castro. If their enthusiasm can be 
expanded and channelled into constructive conservation efforts, then the prospects for this population's survival will be improved if not ensured.

Meanwhile, surveys for the Sierra Madre Sparrow should continue, along with efforts to locate, protect and enhance bunchgrass stands and adjacent marshy areas throughout the species' historic range. Such steps would provide habitat not only for surviving populations, but also for any expansion that they might undergo over time.

\section{Acknowledgements}

We are grateful to John P. Hubbard who provided ideas, information and valuable comments to improve the manuscript. We also thank Alejandro Espinoza, Lorrain Giddings, Adolfo Navarro, Ken Oyama and an anonymous reviewer, for their comments on this manuscript. We give special thanks to the people of the Ejido Ojo de Agua-El Cazador, and especially to Comisariado Ejidal Don Julio Castro, as well as to all the many people who provided help and information during our search for the Sierra Madre Sparrow in the Sierra Madre Occidental. We also thank the E. Alexander Bergstrom Research Award from the Association of Field Ornithologists, the Neotropical Bird Club Conservation Award Scheme and the Centro de Investigaciones en Ecosistemas (CIECO) of the Universidad Nacional Autónoma de México for financing the fieldwork; CONACyT for the master's scholarship granted to the first author and the DGEP-UNAM for the compliment to the same; Instituto de Ecología, A.C. of Xalapa for the postdoctoral scholarship granted to the second author; the Dirección General de Vida Silvestre (DGVS-SEMARNAT) for the licence FAUT oo34 used for banding; the Birders' Exchange Program from the American Birding Association for providing a telescope, tripod and camera; the curators of the diverse ornithological collections who facilitated the historical data of the species for the Atlas of the Birds of Mexico (British Museum Natural History, Museum of Comparative Zoology, Moore Laboratory of Zoology, American Museum of Natural History, Bell Museum of Natural History, Delaware Museum of Natural History, Royal Ontario Museum, Canadian Museum of Nature, University of Michigan, and Carnegie Museum of Natural History) and Alejandro Gordillo, Museo de Zoología, Facultad de Ciencias UNAM for providing georeferences of the localities; and Adriana Garza, Patricia Geréz, Héctor Gómez de Silva, Borja Milá, Nidia Pérez, Sofía Solórzano and Miguel Soto for their support in the planning and discussion of the project.

\section{References}

AOU (1998) Check-list of North American birds. Seventh edition. Lawrence, Kansas: American Ornithologists' Union.

Bailey, A. M. and Conover, H. B. (1935) Notes from the State of Durango, Mexico. Auk 52: 421-424.

Bangs, O. (1931) A new genus and species of American buntings. Proc. N. Engl. Zool. Club 12: $85-88$.

BirdLife International. (2004) Species factsheet: Xenospiza baileyi. Downloaded from http://www.birdlife.org on 13 February 2005

Dickerman, R. W., Phillips, A. R. and Warner, D. W. (1967) On the Sierra Madre Sparrow, Xenospiza baileyi, of Mexico. Auk 84: 61-71.

Geupel, G. R. and Hardesty, D. (1996) The Palomarin handbook. Point Reyes Bird Observatory, U.S.A. 
Goldman, E. A. (1951) Biological investigations in Mexico. Smithsonian Mis. Coll. Vol. 115 (whole volume).

Howell, S. N. G. (1999) A bird-finding guide to Mexico. Cornell University Press, U.S.A.

Howell, S. N. G. and Webb, S. (1995) A guide to the birds of Mexico and northern Central America. New York: Oxford University Press.

Lammertink, J. M. (1999) In Species factsheet: Xenospiza baileyi. Downloaded from http://www.birdlife.org on 13 February 2005.

Miller, A. H., Friedmann, H., Griscom, L. and Moore, R. T. (1957) Distributional check-list of the birds of Mexico: part 2. Pacific Coast Avifauna no. 33.

Navarro, A. G., Peterson, A. T. and Gordillo-Martínez, A. (2002) A Mexican case study on a Centralized Data Base from World Natural History Museums. CODATA, Data Sci. J. I: $45-53$.

Oliveras de Ita, A. (2002) Dinámica poblacional e historia natural del Gorrión Serrano (Xenospiza baileyi). Bachelor's thesis. Facultad de Ciencias, UNAM, México, D.F.

Oliveras de Ita, A. and Gómez de Silva, H. (2002) Nueva localidad para el Gorrión Serrano (Xenospiza baileyi). Orn. Neotrop.13: 203-204.

Oliveras de Ita, A., Gómez de Silva, H. and Grosselet, M. (2001) Population dynamics and natural history of the Sierra Madre Sparrow (Xenospiza baileyi) at La Cima, Mexico. Cotinga 15: 43-47.

Pitelka, F. A. (1947) Taxonomy and distribution of the Mexican sparrow Xenospiza baileyi. Condor 49: 199-203.

Robins, J. D. and Schnell, G. D. (1971) Skeletal analysis of the Ammodramus-Ammospiza grassland sparrow complex: a numerical taxonomic study. Auk 88: 567-590.

\section{ADÁN OLIVERAS DE ITA}

Centro de Investigaciones en Ecosistemas (CIECO), Universidad Nacional Autónoma de México, Antigua Carretera a Patzcuaro No.8701. C.P. 58190, Morelia, Michoacán, México

OCTAVIO R. ROJAS-SOTO

Instituto de Ecología, A.C., Departamento de Biología Evolutiva, Km 2.5 Carretera Antigua a Coatepec No. 351, Congregación el Haya, C.P. 91070, Xalapa, Veracruz, México

Received 16 November 2004; revision accepted 14 March 2005 